\title{
Macrophage Migration Inhibitory Factor
}

National Cancer Institute

\section{Source}

National Cancer Institute. Macrophage Migration Inhibitory Factor. NCI Thesaurus. Code C28467.

Macrophage migration inhibitory factor (115 aa, $\sim 12 \mathrm{kDa}$ ) is encoded by the human MIF gene. This protein is involved in the regulation of the innate immune response. 